\title{
Zkvalitnění monitoringu biologické kvality pitných vod
}

\section{PŘEMYSL SOLDÁN, LIBOR RAMBOUSEK}

Klíčová slova: havarijní znečištění - teroristické útoky na vodní zdroje kriminální činnost zaměřená na vodní zdroje - kontinuální biologický monitoring

\section{SOUHRN}

Příspěvek podává informaci o zavádění nové metody kontinuálního monitoringu biologické jakosti surových a upravených vod na Úpravně vod Želivka. Jedná se o největši úpravnu vody pro hlavní město Prahu. Kromě toho úpravna zásobuje pitnou vodou i oblasti Středočeského kraje a kraje Vysočina. Zaváděný biologický monitoring představuje v České republice zcela nový prístup ke sledování biologické jakosti pitných vod. To je dáno typem použitých monitorovacích zařízení (DaphTox), která jsou v České republice pouze ve dvou exemplárích. V článku jsou popsány zkušenosti se zaváděním zkušebního provozu monitorovacích zařízení včetně popisu nezbytná opatření pro zajištění jeho chodu.

\section{ÚVOD}

Úpravna vody Želivka, a. s., a její dceřiná společnost Želivská provozní, a. s., jsou vodárenské společnosti, které se podílejí na správě a provozování Středočeské vodárenské soustavy. Podle údajů, zveřejněných na webových stránkách akciové společnosti, byla úpravna uvedena do provozu v roce 1972. Surová voda je do úpravny dodávána z vodárenské nádrže Švihov, která má objem vody 266,5 milionů $\mathrm{m}^{3}$. Základní technologií úpravy vody je koagulační filtrace s dávkováním síranu hlinitého. Pitná voda je zdravotně zabezpečena ozonem a chlorem. Maximálním projektovaným špičkovým výkonem $7 \mathrm{~m}^{3} / \mathrm{s}$ pitné vody a současným výkonem okolo $3 \mathrm{~m}^{3} / \mathrm{s}$ pitné vody se raadí úpravna vody Želivka k největším úpravnám vody $v$ Evropě a je největší úpravnou vody v České republice.

Úpravna vody Želivka je největší úpravnou vody pro hlavní město Prahu. Doprava pitné vody do Prahy je zajištěna štolovým přivaděčem o délce 51,97 km do vodojemu Jesenice I u obce Vestec. Podíl Úpravny vody Želivka na zásobování Prahy pitnou vodou se pohybuje okolo 74 \% a zbytek zajištuje dodávkami Úpravna vody Káraný, Úpravna vody Podolí slouží jako rezervní zdroj (z údajů Pražských vodovodů a kanalizací). Úpravna vody Želivka dále zásobuje pitnou vodou i oblasti Středočeského kraje a kraje Vysočina. Nezávadné pitné vody nesmí vykazovat nežádoucí biologické účinky. Bezpečný zdroj pitné vody má strategický význam pro jakékoliv lidské sídlo. S velikostí sídla se jeho význam zvyšuje, je tedy jasné, že zajištění bezpečného zdroje pitné vody pro Prahu a okolí má nejvyšší prioritu. Riziko náhlé kontaminace vod nebezpečnými látkami je samozřejmě vyšší u povrchových zdrojů surových vod, tak jako je to v př́padě Úpravny vod Želivka. V současné době k náhodným prípadům kontaminace přistupuje i riziko cílené kriminální či teroristické akce. Protože náhlé zhoršení kvality vody pro úpravu má charakter náhodného jevu, je nutné na úpravnách vybudovat systém včasného varování, který by dostatečně rychle, s potřebnou citlivostí a hlavně spolehlivě detekoval změny kvality surových vod pro úpravu. Tento Koncept II se zabýval vylepšením systému včasného varování na Úpravně vod Želivka.

\section{SYSTÉM VČASNÉHO VAROVÁNÍ}

Protože úprava pitných vod je nepřetržitý proces, musíme pro potřeby zajištění bezpečnosti produkce disponovat okamžitými informacemi jak o kvalitě surových vod, pritékajících na úpravnu, tak o vodách, odváděných z úpravny do vodovodní sítě. Zdrojem okamžitých informací může být pouze kontinuální monitoring. Rutinně prováděný kontinuální monitoring povrchových vod v České republice zahrnuje sledování vybraných fyzikálně-chemických parametrů (pH, obsah rozpuštěného kyslíku, vodivost, teplota, UV absorbance při vinové délce $254 \mathrm{~nm}$ ). Tyto údaje jsou zcela nedostatečné pro posouzení možných nežádoucích biologických vlastností vod, zejména těch způsobených toxickými účinky znečištění [1].

Ostatní, vysoce specializované chemické analýzy potřebám systému včasného varovaní rovněž nevyhovují. Nelze je totiž provádět $v$ kontinuálním režimu a existuje tedy reálné riziko nezachycení vlny kontaminace vod. Navíc jsou tyto analýzy prováděny cíleně, velice přesně stanovujeme koncentraci určité látky ve vodě, avšak charakter a chemické složení náhodné kontaminace není známo, tím je detekční schopnost stanovení významně snížena. V neposlední řadě si také musíme uvědomit, že i velice přesná data o složení kontaminujících látek nic nevypovídají o jejich konečném biologickém účinku. Musíme si totiž uvědomit, že výsledný účinek je dán fyziologickou dostupností těchto látek a je také zásadně ovlivněn vzájemnou interakcí všech látek ve vodě obsažených. Z těchto skutečností vyplývá, že potřeby systému včasného varování nejlépe naplňuje kontinuální biologický monitoring, kdy jsou vybrané monitorovací organismy nepřetržitě vystaveny působení sledovaných vod a posouzení biologických vlastností těchto vod vychází z vyhodnocení reakce těchto organismů na celkové složení těchto vod. Z výše uvedených důvodů většina vodárenských firem v České republice zavedla kontinuální biologický monitoring pomocí sledování reakce pstruhů duhových na kvalitu surových vod, protékajících nádržemi, v nichž jsou umístěni. Problematice použití pstruha duhového pro monitoring v úpravnách vod se věnují zejména rybář̌ší odborníci z Jihočeské univerzity [2]. Tito autoři se však přednostně soustředují na histopatologická vyšetření monitorovacích ryb a analýzy obsahu polutantů v rybích tkáních, tedy na ukazatele dlouhodobých vlivů monitorovaných vod na ryby, nikoliv na krátkodobé výkyvy biologické jakosti vod, které sledujeme systémem včasného varování. Také na Úpravně vody Želivka je provozován kontinuální 
monitoring pro potřeby systému včasného varování. Systém sledování je řizen Pracovním postupem provozního ředitele č. 3/2007. Na této úpravně jsou pstruzi umístěni ve dvou skleněných nádržích, kterými protéká surová voda přiváděná na úpravnu. Ryby jsou nepřetržitě monitorovány pomocí kamery a jejich reakce vyhodnocují určení zaměstnanci úpravny. Při šetření na místě bylo zjištěno, že ryby $v$ obou nádržích jsou v dobrém zdravotním stavu a vykazují značné přírưstky, ty jsou dány zřejmě vyšším prísunem krmiva. S ohledem na velikost ryb je hustota ryb v obou nádržích značně vysoká, což může negativně ovlivnit „citlivost" odečtu nestandardního chování jedincư při prípadné nevyhovující biologické jakosti vod. Důležité je si také uvědomit fakt, který uvádějí někteří autoři (např. [3]), že totiž vyšší hustota rybí obsádky může vést k zvýšení agresivity monitorovacích ryb a k jejich vzájemnému napadání. Sledovací kamera je umístěna relativně daleko od nádrží, což sice umožní komplexní pohled na nádrže, ale je tím snižena „citlivost“ odečtu. Biologický monitoring je nasazen pouze na vstupu vod do úpravny, nikoliv na výstupu. Není tedy monitorována biologická jakost vod odváděných do vodovodní sítě po procesu úpravy surových vod, který může vést ke vzniku různých reakčních meziproduktů, které mohou působit negativní biologické účinky.

\section{METODA ŘEŠENÍ}

Podle doporučení americké agentury ochrany životního prostředí [4] by každý ucelený biologický systém včasného varování (BSVV), který je založen na vyhodnocování reakcí živých organismů, měl splňovat tři základní požadavky. Musí poskytovat rychlou odpověd", detekovat škálu odlišných kontaminant, ale zároveň si musí zachovat dostačující citlivost. Posledním významným kritériem je, že musí pracovat jako automatizovaný systém, který umožňuje dálkovou kontrolu. Jakýkoliv BSVV, který nesplňuje tyto tři základní charakteristiky, není považován za efektivní varovný systém.

Současný systém sledování kvality vod, pritékajících na úpravu vody Želivka tyto požadavky nesplňuje. Vykazuje nedostatky, které významně ovlivňuji jeho vypovídací schopnost a tím i celkovou úroveň kontroly biologických vlastností povrchových vod určených pro výrobu pitné vody především pro Prahu. Cílem aktivity bylo zavedení nové kontinuální metody sledování biologických vlastností vod, které výrazně zvýší efektivitu, citlivost a operativnost celého monitorovacího systému úpravny oproti v současnosti používané metodě. Současně má být tento kontinuální monitoring schopný zachytit prípadné negativní vlivy technologie úpravy vod na její biologické vlastnosti. Vytyčeného cíle Ize dosáhnout zavedením použití prístrojů pro biologický monitoring, disponujících kontinuálním počítačovým vyhodnocováním reakce monitorovacích organismů spojeným s automatickým upozorněním na závažnou změnu jakosti sledovaných vod. Základní myšlenka využívání automatických biologických senzorů ke sledování kvality vody byla poprvé vyslovena na počátku sedmdesátých let [5]. Od té doby došlo k výraznému rozvoji v této oblasti. Celosvětově existuje řada firem, které komerčně nabízejí přístroje pro provádění automatizovaného kontinuálního biologického monitoringu.

Tyto přistroje jsou využívány nejen k monitoringu jakosti vod v povodích, ale účelově také na úpravnách vod. Jako príklad uvádíme Úpravnu vod Stakčín na Slovensku $[3,6]$. Na této úpravně jsou na prívodu surové vody osazeny dva druhy prístrojů, FISH monitor firmy Kerren (SRN), využívající jako monitorovací organismus pstruha duhového a MOSSEL monitor firmy Delta Consult (Nizozemsko), který využívá jako monitorovací organismus měkkýše druhu Unio pictorum a Unio tumidus. Obě zařízení fungují kontinuálně s automatickým vyhodnocováním biologického stavu monitorovaných vod a spuštěním alarmu v prípadě překročení limitních hodnot. Dunaj [3] v závěru své práce konstatuje, že zavedený systém biologického monitoringu se plně osvědčil. Systém umožňuje $v$ prípadě nežádoucí změny kvality surových vod urychleně prikikročit k odstavení úpravny, zjištění príícin této změny a prrijetí potřebných opatření.
Oceňovaná je vysoká citlivost prístrojů a rychlost reakce na změny biologické jakosti vody. V případě Úpravny vody Želivka jsme zvolili nasazení př́strojů DaphTox firmy BBE Moldaenke (SRN) na vstupu a výstupu vod z úpravny. Pro výběr tohoto typu monitorovacího zařízení byly rozhodující následující parametry:

- citlivost zařizení,

- relativní nenáročnost obsluhy,

— úroveň prověření rutinním provozem.

Citlivost zařizení je dána použitím testovacího organismu a způsobem vyhodnocení jeho reakcí. $V$ prípadě prístroje DaphTox jsou jako monitorovací organismy použity perloočky Daphnia magna. Tyto organismy vykazují vysokou citlivost na širokou škálu polutantů. Pro případ sledování jakosti vody z nádrže je také významná vysoká citlivost perlooček na vliv toxinů, produkovaných sinicemi. Nebezpečí kontaminace vod těmito látkami je velmi vysoké v letním období. Řada autorů [7-14] považuje tyto organismy za nejvhodnější pro zkoušky toxicity toxinů sinic pro jejich vysokou citlivost na dané látky. Naopak pstruzi a ryby obecně vykazují k těmto toxinům velice nízkou citlivost. Ani vysoké dávky na ně nepůsobily negativně, včetně nulového poškození hepatopankreatu.

Vyhodnocení reakce perlooček, použitých $k$ monitoringu $v$ prístrojích DaphTox, zahrnuje už změny chování, tedy možné neletální negativní účinky znečištění vod. Pohyb organismů v měřicí cele kontinuálně snímá CCD kamera. Změny chování jsou průběžně vyhodnocovány integrovaným počítačem. Pro tyto potřeby firma BBE Moldaenke vyvinula specializovaný software. Jím je převáděn obrazový záznam do grafické a posléze numerické podoby (viz obr. 1).

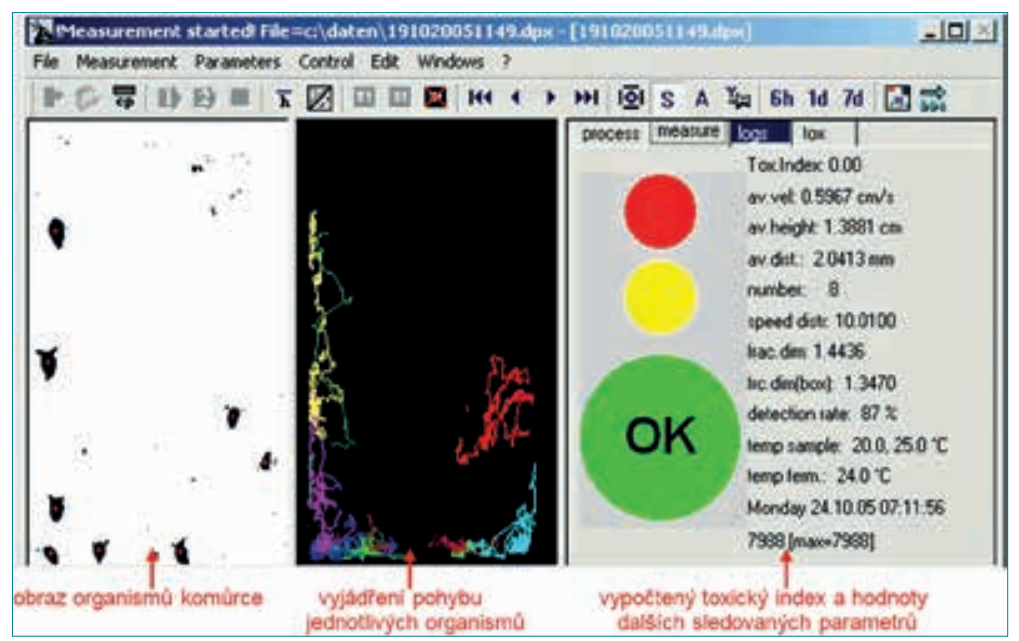

Obr. 1. Kamerový obraz a jeho převod do grafické a numerické podoby Fig. 1. Camera image and its conversion into graphic and numerical form

Chování organismů je vyhodnocováno na základě řady vypočtených parametrů, které zohledňují např́klad průměrnou rychlost pohybu organismů, jejich polohu v komůrce a také jejich úhyn. Z rady dat je stanoven tzv. index toxicity 0 až 10 (viz obr. 2). Na základě jeho hodnoty je pak spouštěno varování či alarm. Hraniční hodnoty pro varování a alarm jsou různé v závislosti na volbě citlivosti monitoringu. Obecně platí neprímá závislost hodnoty toxického indexu na výši zvolené citlivosti. K zařizení se Ize za pomocí specializovaného programu připojit on-line $v$ síti internet z kteréhokoliv počítače, který je daným softwarem vybaven. To umožňuje získávat odkudkoliv a kdykoliv aktuální informace o stavu biologické jakosti vod v monitorovaném profilu.

Náročnost obsluhy nevyžaduje specializované znalosti a obsluhu př́stroje Ize plnohodnotně zajistit po patřičném zaškolení. 


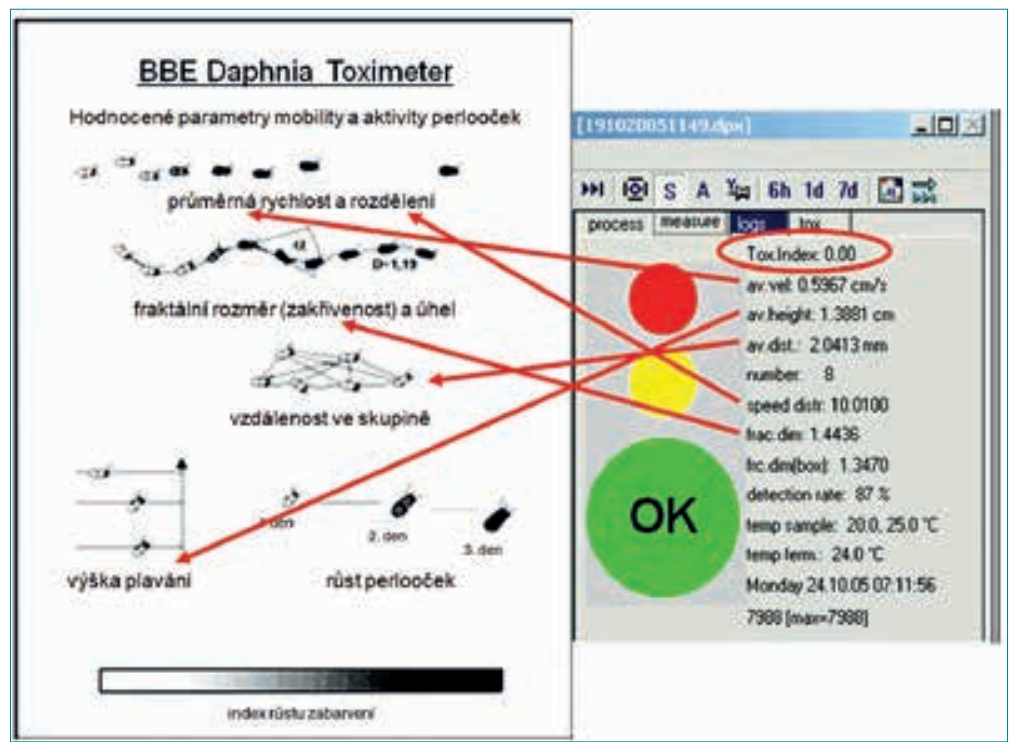

Obr. 2. Vyhodnocení indexu toxicity na základě vyhodnocení různých parametrů cho vání monitorovacích organismů

Fig. 2. Evaluation of toxicity index based on the assessment of various behavioural parameters of monitoring organisms
Úroveň prověření rutinním provozem je u přístrojů DaphTox značná. Kromě toho, že jsou tyto prístroje instalovány na velké řadě monitorovacích stanic situovaných na řekách všech významných evropských povodí, slouží také celosvětově při monitoringu jakosti vod ve vodárenství a potravinářském průmyslu (viz tabulka 1 uvádějící přehled uživatelů, poskytnutý výrobcem přístroje).

Oba př́stroje DaphTox, které jsme osadili na Úpravně vod Želivka, byly dlouhodobě otestovány ve zkušebním provozu na řícních monitorovacích stanicích v povodí řeky Odry. Za dobu použití se plně osvědčily a jasně prokázaly svou užitečnost pro výrazné zlepšení systému včasného varování [1]. Přístroje jsou doplněny automatickým vzorkovačem, který v prípadě zaznamenání havarijního snižení biologické jakosti sledovaných vod odebere vzorky pro následné analýzy, zaměřené na detekci príčin daného stavu.

\section{PRŮBĚH ZAVÁDĚNÍ NOVÉHO TYPU MONITORINGU}

\section{Instalace zařízení a zavedení chovu monitorovacích organismů}

V prípravné fázi probíhaly konzultace s provozovatelem úpravny a šetření na místě osazení prístrojů, zaměřené na technické řešení napojení přístrojů na přívod surových a upravených vod úpravně. Zde musíme konstatovat, že provozovatel úpravny po celou dobu přistupoval k rešení problému velmi aktivně.

Tabulka 1. Užití prístroje DaphTox ve vodárenství a potravinářském průmyslu podle údajů BBE Moldaenke

Table 1. Use of DaphTox device in the waterworks and food industry according to BBE Moldaenke data

\begin{tabular}{|c|c|c|c|c|}
\hline Země & Uživatel & Použití & Od roku & Typy vod \\
\hline Brazílie & HEINEKEN Brasil Jacaref & pivovarnictví - monitoring jakosti vod & 2011 & povrchové/podzemní vody \\
\hline \multirow{3}{*}{ Německo } & Stadtwerke Konstanz & monitoring pitných vod & 2005 & vody z nádrže \\
\hline & Warsteiner & pivovarnictví - monitoring jakosti vod & 2013 & podzemní vody \\
\hline & $\begin{array}{l}\text { Zweckverband Bodensee-Wasserversorgung } \\
\text { Sipplingen } \\
\text { Lake Constance Water Supply Association - BWV }\end{array}$ & monitoring pitných vod & 2009 & vody z nádrže \\
\hline Izrael & $\begin{array}{l}\text { Mekorot Water Co. Nazareth - Illit } \\
\text { National Water Company }\end{array}$ & monitoring pitných vod & 2008 & neznámé \\
\hline \multirow{2}{*}{ Nizozemsko } & Het Waterlaboratorium Nieuwegein & monitoring pitných vod & 2007-2009 & říční vody/vody z nádrže \\
\hline & WML Maastricht & monitoring pitných vod & 2009 & říční vody/vody z nádrže \\
\hline \multirow{2}{*}{ Švýcarsko } & Zurich Water Company Zurich & monitoring pitných vod & 2013 & vody z nádrže \\
\hline & $\begin{array}{l}\text { IWB/Industrielle Werke Basel } \\
\text { Water and Energy Company }\end{array}$ & monitoring jakosti vod & 2011 & neznámé \\
\hline USA & Salt Lake City Water Works & monitoring pitných vod & $2001-2002$ & podzemní vody \\
\hline Ukrajina & Úpravna vod Desna & monitoring pitných vod & 2015 & podzemní vody \\
\hline
\end{tabular}




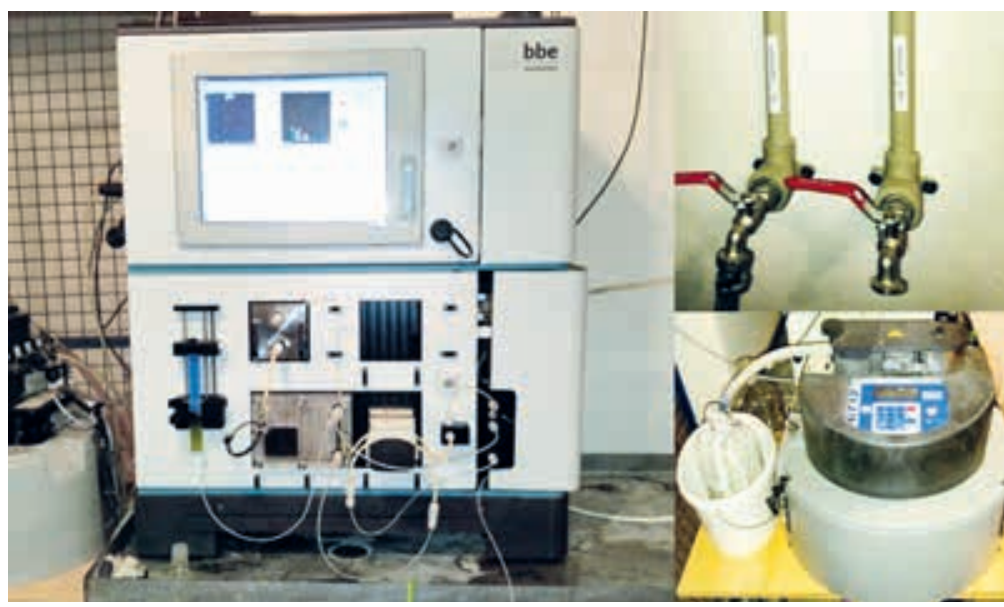

Obr. 3. Monitorovací zařízenís automatickým odběrákem nainstalované na Úpravně vod Želivka

Fig. 3. Monitoring device with automatic sampler installed at the Želivka Water Treatment Plant

Technicky zajistil prostory pro instalaci prístrojů i přívody obou druhů vod Spolupracoval také v činnostech nezbytných $\mathrm{k}$ zajištění on-line připojení přístrojů k internetové síti. Provozovatel také poskytl prostory vhodné pro chov monitorovacích organismů (perlooček) a pěstování krmných planktonních řas.

Po laboratorním otestování plné funkčnosti a provedení nezbytných úprav byl ve vyhrazených prostorách nainstalován první monitorovací prístroj (obr. 3) propojený s automatickým vzorkovačem a zahájen chov monitorovacích organismů a pěstování řas. Nastavením připojení pres internetovou sít bylo rovněž zahájeno on-line sledování reakce monitorovacích organismů. Před zahájením zkušebního provozu byly v prostorách úpravny provedeny toxikologické zkoušky, zaměřené na detekci prípadných negativních biologických účinků sledovaných typů vod na monitorovací organismy, to je perloočky Daphnia magna.

Standardizovanými postupy [15] byly ověřeny účinky surových vod, vod po úpravě a pro porovnání také standardizované redící vody připravené podle ČSN EN ISO 6341 [15]. Zatímco standardizovaná redící voda při době expozice 48 h nevykazovala žádné negativní účinky, surová voda již negativní účinky na monitorovací organismus $v$ omezené míre vykazovala. K rychlému úhynu 100 \% organismů došlo u testovaných vod prošlých úpravnickým procesem. Těmto výsledkům plně odpovídalo ověření v monitorovacím zařízení DaphTox, kdy v průběhu zkušebního monitoringu docházelo k úhynu monitorovacích organismů v rozsahu odpovídajícím výsledkům standardizovaných zkoušek. Problémy s oběma druhy vod tedy bylo nutné vyřešit.

\section{Předúprava surových vod}

U surové vody jsme vyvozovali, že má zřejmě odlišné biologické vlastnosti od standardní ředící vody, ve které byly monitorovací organismy původně chovány. Pro adaptaci organismů na tuto vodu byly chovy převedeny do surové vody. Předpokladem bylo, že nově narozené generace, chované v surové vodě, by měly být na dané médium adaptovány. Tento krok však nepřinesl žádoucí výsledek - k úhynu monitorovacích organismů v DaphToxu docházelo i u jedinců z nově založených chovů, i když samotné chovy vykazovaly plnou adaptaci na surovou vodu. Společným hledáním příčin provedeným jak řešitelem konceptu, tak pracovníkem úpravny byla jako možný negativní faktor určena nízká koncentrace rozpuštěného kyslíku v monitorované surové vodě. Tato voda je totiž odebírána z větších hloubek nádrže, kde výrazně klesá koncentrace rozpuštěného kyslíku. Daný predpoklad byl doložen výsledky měření prováděnými laboratořemi úpravny. Z těchto výsledků vyplynulo, že minimální koncentrace kyslíku mohou dosahovat až hodnoty 4,19 mg/l, což je 36,7 \% nasycení (údaj z roku 2019). Tato úroveň je pro život perlooček nevyhovující, například norma ČSN EN ISO 6341 [15] doporučuje vzorky s koncentrací kyslíku nižší než 40 \% před provedením zkoušky toxicity provzdušnit (a to se zkoušky provádějí v otevřených nádobách, kde může docházet k volné difuzi kyslíku na rozdíl od komůrky DaphToxu, která je hermeticky uzavřena). Proto jsme provedli úpravu, při níž je monitorovaná surová voda nejdřive vedena do kanystru, ve kterém je provzdušňována, a poté je teprve nasávána do komůrky DaphToxu. Tímto opatřením jsme vyřešili nežádoucí úhyn monitorovacích organismů, způsobený nízkým obsahem kyslíku ve sledované vodě.

\section{Předúprava vod po chloraci}

U vody, která prošla technologickým procesem úpravy, bylo odstranění problému složitější. Do prostor, ve kterých je monitorovací př́stroj umístěn, je totiž přivedena upravená voda již po ozonizaci a chloraci. Tato skutečnost značně komplikuje záměr Konceptu II monitorovat rovněž biologické vlastnosti upravené vody. Chlor je totiž toxická látka. Pro bezproblémové kontinuální sledování je tedy nutná kontinuální dechlorace upravené vody. Nejdřive jsme zkoušeli intenzivní aeraci upravené vody v nádobě, z které byla voda odčerpávána do měřicí komory s monitorovacími organismy. Toto opatření však nebylo dostatečně účinné, protože ve vodě stále zůstávala prưměrná koncentrace zbytkového chloru 0,1 mg/l. Že je tato koncentrace pro monitorovací organismy toxická, bylo ověřeno zkušebním monitoringem. Naše pozorování plně odpovídalo závěrům rešeršní studie, kterou publikoval Mattingley [16]. Ten uvádí, že na celkový zbytkový chlor jsou z širokého spektra vodních organismů nejcitlivější perloočky druhu Daphnia magna. Pro organismy mladší 24 h (tedy ve stáríi, ve kterém se nasazují do monitorovacího zařízení) je koncentrací, která způsobí 50\% úhyn organismů při době expozice 48 h, hodnota 0,017 mg celkového zbytkového chloru na litr. Proto jsme museli hledat efektivnější způsob dechlorace. Pro dechloraci upravených vod jsme se rozhodli využít thiosíran sodný $\left(\mathrm{Na}_{2} \mathrm{~S}_{2} \mathrm{O}_{3}\right)$. Tato látka vykazuje vysokou efektivitu při dechloraci vodných roztoků a zároveň má velice nízké toxické účinky na perloočky Daphnia magna. Basu a Dorner [17] uvádějí, že tato látka do koncentrace 200 mg/l neměla v testech akutní toxicity negativní účinky na perloočky. Danou látku úspěšně použili Zeng a kol. [18] při monitoringu chlorací upravených vod. K těmto vodám kontinuálně přidávali roztok thiosíranu sodného $\left(\mathrm{Na}_{2} \mathrm{~S}_{2} \mathrm{O}_{3}\right)$ ve výsledné koncentraci $v$ monitorovaných vodách $1,75 \mathrm{mg} / \mathrm{l}$. Použití thiosíranu sodného $\mathrm{k}$ dechloraci vodných vzorků doporučuje také TNV 757768 [19]. Tato norma doporučuje použít thiosíran ve výsledné koncentraci 10 mg/l.

My jsme provedli vlastní testy akutní toxicity metodikou podle ČSN EN ISO 6341. Připravili jsme roztoky ve výsledných koncentracích $10 \mathrm{mg} / \mathrm{l}, 20 \mathrm{mg} / \mathrm{l}$, 50 mg/l a 100 mg/l. Při expozici 48 h neměl žádný ze zkoumaných roztokư negativní účinky pro zkušební organismy, jimiž byly perloočky Daphnia magna. Proto jsme se rozhodli k monitorovaným vodám po úpravě přidávat thiosíran ve výsledné koncentraci v monitorovaném médiu 20 mg/l. K tomuto rozhodnutí nás vedlo ověření biologických účinků této látky při snaze o maximální efektivitu dechlorace. Náš záměr byl ověřen měřením, kdy po přídavku thiosíranu k vodám po úpravě opravdu klesl obsah celkového zbytkového chloru na nulovou hodnotu. Zkušební monitoring prokázal neškodnost upravených vod po dechloraci pro monitorovací organismy. Aby bylo možno provádět kontinuální přidávání roztoku thiosíranu k upraveným vodám, bylo třeba monitorovací zařizení (DaphTox) doplnit o další synchronizované peristaltické čerpadlo. Takto upravený prístroj přisává stejné objemy monitorované vody a roztoku thiosíranu. Ty jsou ještě vtokem do komůrky přístroje spojkou sloučeny do jedné přívodní hadičky, takže do monitorovací komůrky přístroje vtéká již surová voda promíchaná s roztokem thiosíranu. Dané opatření se projevilo $v$ negaci toxického účinku chloru na perloočky. 


\section{ZKUŠEBNÍ PROVOZ NAVRHOVANÉHO MONITORINGU}

Po odstranění výše popsaných problémů nyní v prostorách Úpravny vody Želivka probíhá zkušební monitoring obou typů vod, surových i upravených, včetně produkce monitorovacích organismů a krmných řas $v$ prostorách úpravny. V první polovině roku bude pokračovat zaškolování obsluhy a bude vyhotovena doporučená metodika provozování celého systému, která bude této obsluze předána.

\section{ZÁVĚRY}

Zavedení kontinuálního monitoringu pomocí prístrojü DaphTox na Úpravně vody Želivka, prováděné v rámci řešení Konceptu II: Zkvalitnění monitoringu biologické kvality pitných vod, představuje v České republice zcela nový př́stup ke sledování biologické jakosti pitných vod. To je dáno typem použitých monitorovacích zařízení, která jsou v České republice pouze ve dvou exemplárích. Ty jsou ve vlastnictví Výzkumného ústavu vodohospodářského, v. v. i., a jsou Úpravně vody Želivka neúplatně zapůjčeny. Nová strategie systému včasného varování přinese zvýšení efektivity a přesnosti tohoto systému. Toto opatření má zaručit spolehlivější kontinuální kontrolu produkce bezpečné pitné vody pro Prahu a široké okolí, zásobované z této úpravny. Nová metoda monitoringu také reflektuje současnou bezpečnostní situaci, kdy mohou být zdroje pitných vod pro velké sídelní celky ohroženy kriminální či teroristickou činností. Tato situace je výraznou změnou oproti dobám, kdy dodržování zásad, daných pravidly ochranných pásem zdrojů pitných vod, zaručovalo relativně účinnou prevenci jejich nežádoucího znečištění. Pro Prahu a okolí to znamená posílení ochranných mechanismů zajištujujícich základní životní zdroje pro danou oblast.

\section{Poděkování}

Publikované výsledky byly získány v rámci rešení Konceptu II, projektu "Čistá voda zdravé město: Cizorodé látky ve vodách podzemnich, povrchových a odpadních" (registrační čís/o projektu CZ.071.02/0.0/0.0/16_040/0000378), financovaného z fondů Operačníprogram Praha - pól růstu ČR.

\section{Literatura}

[1] SOLDÁN, P. Possible Way to Substantial Improvement of Early Warning System in the International Odra (Oder) River Basin. Environmental Monitoring and Assessment, 2011, Vol. 178, No. 1-4, p. 349-359. ISSN 0167-6369.

[2] RANDÁK, T., ŽLÁBEK, V., TUREK, J., VELIŠEK, J. a KOLÁŘOVÁ, J. Využitípstruha duhového (Oncorhynchus mykiss) pro účely ekotoxikologického monitoringu kvality vody. Edice Metodik (technologická rada) č. 111, FROV JU, Vodňany, 2011, 25 str.

[3] DUNAJ, J. Systém skorého varovania pomocou biologického monitoringu pri výrobe pitnej vody na úv Stakčín. Dostupné z: http://wtwsk.2ka.cz/upload/files/BEWS__UV_Stakcin.pdf

[4] US EPA. Technologies and Techniques for Early Warning Systems to Monitor and Evaluate Drinking Water Quality: A State of the Art Review. U.S. Environmental Protection Agency Office of Water Office of Science and Technology Health and Ecological Criteria Division. Washington, 2005, 236 p.

[5] GUNATILAKA, A. and DIEHL, P. A brief review of chemical and biological continuous monitoring of rivers in Europe and Asia. In: BUTTERWORTH, F.M. et al. Biomonitors and biomarkers as indicators of environmental change 2. Kluwer Academic/Plenum Publishers, New York, 2000, p. 9-28.

[6] BRATSKÁ, Z a RIGANOVÁ, N. Kvalita ve vodnei nádrži Starina. Dostupné z: https://www.smv.cz/res/ archive/051/005760.pdf?seek=1429083269

[7] FERRAO-FILHO, A.S., AZEVEDO, S.M.F.O., and DEMOTT, W.R. Effects of toxic and non-toxic cyanobacteria on the life history of tropical and temperate cladocerans. Freshwater Biology, 2000, 45, p. 1-19.

[8] VASCONCELOS, V. Cyanobacteria Toxins: Diversity and Ecological Effects. Limnetica, 2001, Vol. 20, No. 1, p. 45-58. ISSN 0213-8409.

[9] BLANCHETTE, M.L. and HANEY, J.F. The effect of toxic Microcystis aeruginosa on four different populations of Daphnia. UNH Center for Freshwater Biology Research, 2002, Vol. 4, No. 1, p. 1-10.

[10] AGRAWAL, M., YADAV, S., PATEL, C., RAIPURIA, N., and AGRAWAL, M.K. Bioassay methods to identify the presence of cyanotoxins in drinking water supplies and their removal strategies. European Journal of Experimental Biology, 2012, Vol. 2, No. 2, p. 321-336.

[11] BOWNIK, A. Effects of Cynobacterial Toxins, Microcistins on Freshwater Invertebrates. Polish Journal of Natural Sciences, 2013, Vol. 28, No. 2, p. 185-195

[12] ZANCHETT, G. and OLIVEIRA-FILHO, E.C. Cyanobacteria and Cyanotoxins: From Impacts on Aquatic Ecosystems and Human Health to Anticarcinogenic Effects. Toxins, 2013, 5, p. 1896-1917. DOI: 10.3390/toxins5101896

[13] SCHMIDT, J.R., WILHELM, S.W., and BOYER, G.L. The Fate of Microcystins in the Environment and Challenges for Monitoring. Toxins, 2014, 6, p. 3354-3387. DOI: 10.3390/toxins6123354.

[14] HERRERA, N.A., ECHEVERRI, L.F., and FERRAO-FILHO, A.S. Effects of phytoplankton extracts containing the toxin microcystin-LR on the survival and reproduction of cladocerans. Toxicon, 2015, 95, p. 38-45.

[15] ČSN EN ISO 6341 (757751) Kvalita vod - Zkouška inhibice pohyblivosti Daphnia magna Straus (Cladocera, Crustacea) - Zkouška akutní toxicity.

[16] MATTINGLEY, L. The impact of chlorine and chlorinated compounds in freshwater systems. Salmon \& Trout Conservation, 2017,7 p. Dostupné z: https:/www salmon-troutorg/wp-content/ uploads/2017/09/STC-The-impact-of-chlorine-and-chlorinated-compounds-in-freshwater-systems. pdf

[17] BASU, O.D. and DORNER, S.M. Potential Aquatic Health Impacts of Selected Dechlorination Chemicals. Water Qual. Res. J. Can., 2010, Vol. 45, No. 3, p. 353-363.

[18] ZENG, Y., FU, X., and REN, Z. The Effects of Residual Chlorine on the Behavioural Responses of Daphnia magna in the Early Warning of Drinking Water Accidental Events. Procedia Environmenta Sciences, 2012, 13, p. 71-79.

[19] TNV 757768 Jakost vod - Hodnocení účinnosti čištění průmyslových odpadních vod pomoc toxikologického stanoveni 


\section{Autoři}

RNDr. Přemysl Soldán, Ph.D.'

凶. premysl.soldan@vuv.cz

Libor Rambousek ${ }^{2}$

网rambousek@zelivska.cz

'Výzkumný ústav vodohospodářský T. G. Masaryka, v. v. i., pobočka Ostrava ¿úpravna vody Želivka

Př́spěvek prošel lektorským řízením.
IMPROVEMENT OF MONITORING

\section{OF BIOLOGICAL QUALITY}

OF DRINKING WATER

\section{SOLDAN, P.'; RAMBOUSEK, L. ${ }^{2}$}

'TGM Water Research Institute, p.r.i., Ostrava Branch

2Želivka Water Treatment Plant

Keywords: accidental pollution - terrorist attacks on water resources criminal activities focused on water resources -

continuous biological monitoring

The article provides information on the introduction of a new method of continuous monitoring of the biological quality of raw and treated waters at the Želivka Water Treatment Plant. It is the largest water treatment plant for the capital city of Prague. In addition, this water treatment plant also supplies drinking water to the Central Bohemia and Vysočina regions. Introduced biological monitoring represents a completely new approach to monitoring the biological quality of drinking water in the Czech Republic. This is due to the type of monitoring equipment used (DaphTox), which are only two devices of this type in the Czech Republic. The paper describes the experience with the implementation of trial operation of monitoring equipment, including the description of the necessary measures to ensure its operation.

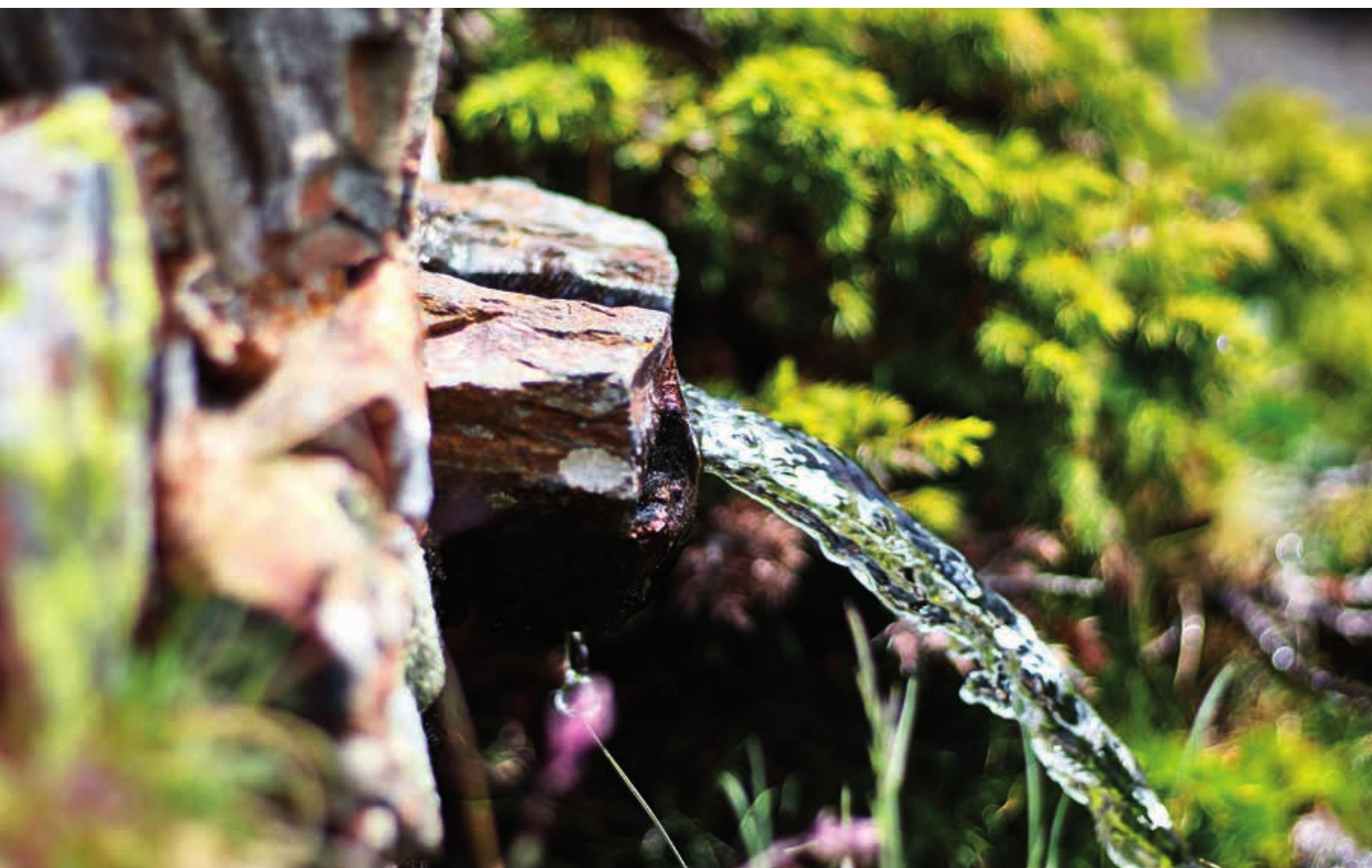

